\title{
Aspectos da lógica estoica e da lógica em Sêneca
}

\author{
Maíra Meyer Bregalda \\ IEL-UNICAMP \\ uenerem@ig.com.br
}

RÉSUMÉ: La logique, dans l'Antiquité, comportait un champ beaucoup plus vaste que celui qu'on attribue aujourd'hui à ce terme e à ses implications. On sait que la logique moderne, contemplée à partir des études actuelles sur le langage, comme la sémantique, a pour objectif de vérifier la validité des divers modes de raisonnement. Cependant, les aspects privilégiés par la logique antique, y compris par la logique stoïcienne, concernent la relation entre les mots et la structure même du langage. La logique stoïcienne est surtout propositionnelle; il s'agit des relations entre des items (axiomes) qui ont une structure de proposition. Notre but, dans cet article, sera d'examiner ces aspects de la logique stoïcienne et de les confronter au traitement de cette partie de la philosophie chez Sénèque. Nous soulignerons, bien que brièvement, les différences entre la logique stoïcienne et celle d'Aristote, en présentant des extraits d'ouvrages qui soient capables d'éclairer les oppositions entre les deux.

MOTS-CLÉS: Sénèque; logique stoïcienne; logique péripathéticienne; philosophie ancienne; sémantique.

\section{Introdução}

Tivemos oportunidade de observar, nas atuais abordagens da lógica em disciplinas de Semântica, que a lógica antiga não é tratada com frequência. Este trabalho, de caráter incipiente, surgiu de tal constatação, e pretende observar mais de perto a presença de procedimentos da lógica antiga em algumas passagens das Epistulae Morales ad Lucilium do filósofo Lúcio Aneu Sêneca (4 a.C.-65 d.C.), um dos principais representantes do estoicismo desenvolvido na época da Roma imperial.

O interesse surgiu após constatarmos uma aparente discrepância no discurso senequiano: apesar de o autor, nas suas epístolas, em geral criticar a preocupação com a formalidade na exposição do pensamento (quer por parte dos oradores e retóricos, quer por parte dos filósofos e filólogos), não raro nos deparamos, no texto da obra, com os elementos criticados - como, por exemplo, o uso de silogismos da dialética. ${ }^{1}$

No decorrer do estudo, observamos que, na lógica antiga, e particularmente nas passagens específicas selecionadas na nota abaixo, ${ }^{2}$ trata-se de elementos que hoje são objeto de diversas áreas dos estudos da linguagem, como a abordagem do aspecto

\footnotetext{
${ }^{1}$ Sobre tal crítica, cf. nossa tradução e análise das cartas 20, 1-2; 48, 4; 6; 10-12; 88, 36-38, in Bregalda, M. M. Sapientia e uirtus. Princípios fundamentais no estoicismo de Sêneca. Campinas: IEL-UNICAMP, 2006, p. 9-11(dissertação de mestrado).

${ }^{2}$ Cf. Sêneca, Ep. 45, 5; 48, 4; 6; 83, 9; 85, 30-37; 117, 13; Quintiliano, Institutio oratoria V 14, 1; Diógenes Laércio, Lives of eminent philosophers, VII 63; VII 65-8; Plutarco, Moralia, 1011e; Sexto Empírico, Ad. Math., VIII 70; Cícero, De diuinatione I 38, 82.
} 
formal do discurso em $\mathrm{si}^{3}$

A fim de observar melhor a presença de elementos lógicos em Sêneca, primeiro foi necessário investigar que tipo de lógica a ele seria disponível. Nesse sentido, nossa exposição vai-se iniciar com uma apresentação, forçosamente breve, de alguns dos aspectos importantes da lógica estoica, contrastando-a com elementos da lógica peripatética. Para isso nos valemos do quinto capítulo do livro The Stoics, de F. H. Sandbach, e do quarto do livro Hellenistic Philosophy, de A. A. Long.

Ao trabalhar com o texto senequiano propriamente dito, traduzimos trechos selecionados de suas Epistulae $e^{4}$ e, a seguir, discutimos sobre o valor efetivo dessa parte da filosofia para o cordovês e suas implicações. Ver-se-á que, nas cartas analisadas, Sêneca tende a diferir, inclusive, dos mestres de sua escola, no que concerne à abordagem de silogismos e da importância conferida a essa disciplina.

\section{Breve exposição da lógica para os antigos estoicos}

A lógica estoica é uma lógica proposicional, ${ }^{5}$ isto é, que diz respeito a relações entre itens que têm estrutura de proposições. Esses itens são os axiomas ( $\alpha \xi i$ io $\mu \alpha \alpha)$ ). De acordo com isso, a lógica estoica se divide em duas partes principais: a teoria dos

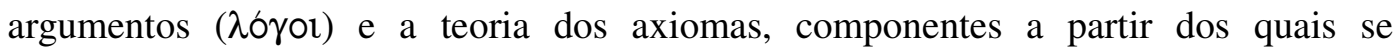
constroem os argumentos. ${ }^{6}$

De acordo com Sandbach, ${ }^{7}$ a lógica estoica teve uma influência limitada na Antiguidade, e as informações que sobre ela restaram são fragmentadas. Além disso, o campo abrangido pelo que hoje se entende pela palavra "lógica" - a saber, a "ciência do raciocínio", ou, ainda, "que descobre e formula as leis do pensamento claro"9 - era muito mais amplo naquela época. Lógica, para os estoicos, sendo a ciência do lógos -

\footnotetext{
${ }^{3} \mathrm{O}$ reconhecimento e a nomeação das partes do discurso, os casos dos nomes e os tempos verbais, dos quais se ocupa, entre outras áreas, a Semântica atual, foram uma das realizações da escola estóica. Sobre tal relação, cf. Sandbach, F. H. The stoics. Second edition. Cambridge: Bristol Classical Press, 1989, p. 95.

${ }^{4}$ As Epistulae Morales ad Lucilium, coleção de 124 cartas que o filósofo teria escrito a seu discípulo Lucílio, compostas durante o período de afastamento de Sêneca da vida pública (entre 62 e 63 d.C.).

${ }^{5}$ Cf. Bobzien, S. Lógica. In: Os estóicos. Tradução de Paulo Fernando Tadeu Ferreira e Raul Fiker. São Paulo: Odysseus, 2006, p. 95-138.

${ }^{6}$ Cf. Bobzien, op. cit., p. 95.

${ }^{7}$ Cf. Sandbach, op. cit., p. 95.

${ }^{8}$ Cf. Chauvineau, J. A lógica moderna. Tradução de André Infante. Lisboa: Europa-América, 1957, p. 7.

${ }^{9}$ Cf. Cerqueira, L.; Oliva, A. Introdução à lógica. Rio de Janeiro: Zahar, 1982, p. 11.
} 
que poderia significar, em grego, tanto "discurso" quanto "razão"10 -, visava ao exame não somente da validade das várias maneiras de raciocínio (aspecto privilegiado na Lógica moderna), ${ }^{11}$ mas também da relação entre as palavras e, ainda, da estrutura da linguagem. ${ }^{12}$ Embora os filósofos gregos Zenão (336-264 a.C.) ${ }^{13}$ e Cleantes (331-232 a.C. $)^{14}$ tenham escrito um pouco sobre o assunto, foi Crisipo $(280-210 \text { a.C. })^{15}$ quem desenvolveu sistematicamente a lógica estoica ${ }^{16}$

Para Aristóteles, coisas individuais diziam respeito a termos universais ${ }^{17}$ : "Se todo A é B, e todo B é C, logo todo A é C" era seu silogismo fundamental. Nessa sentença, é notável que todas as três variáveis (A, B e C) devem ser universais. Consideremos palavras como "rei", "homem" e "mortal", por exemplo. Se elas forem substituídas por variáveis, ter-se-á um silogismo como este: "Se todos os reis são homens e todos os homens são mortais, logo todos os reis são mortais".

Porém, para os estoicos, a única coisa que "existe" é o indivíduo: o universal não passa de uma construção mental (Simplício, ${ }^{18}$ In Ar. Cat., 26). Similarmente, eles desenvolveram uma lógica que trataria de coisas individuais. Ela começou por um tripla distinção entre 1, a palavra falada, que é material ( $\sigma \omega \mu \alpha \tau o \zeta$, corporale); 2, o que significa, que é imaterial ( $\alpha \sigma \omega ́ \mu \alpha \tau o s$, incorporale), ${ }^{19}$ sendo "o que se diz" ou "o que

\footnotetext{
${ }^{10}$ De acordo com o dicionário Liddell, H. G.; Scott, R. A Greek-English lexicon. Oxford: Clarendon Press, 1996, s. v., o termo tinha, além dos referidos sentidos, vários outros, entre os quais: I 1. quantidade de dinheiro em mãos; 2. soma, quantia; 3. medida; 4. consideração, valor imputado a uma pessoa ou coisa (...). II 1. relação, correspondência, proporção; III, 1. explanação; 2. base de uma teoria, argumento; 3. lei, regra, etc.

${ }^{11}$ Para ilustrar o que é um raciocínio válido em lógica moderna, tomemos um exemplo típico que é apontado como válido por Chierchia, G. Semântica. Tradução de Luis Arthur Pagani, Lígia Negri e Rodolfo Ilari. Campinas/ Londrina: UNICAMP/ EDUEL, 2003, p. 50: (a) Se Juca está na festa, Maria não está; (b) Juca está na festa; (c) Maria não está na festa. Se nos forem apresentadas (a) e (b), inferimos $(c)$. Observe-se que isso vale para qualquer sequência de sentenças com a seguinte forma: $(a)$ Se A, então $B$; (b) A; (c) B.

${ }^{12}$ Cf. Sandbach, op. cit., p. 95.

${ }^{13}$ Zenão de Cício, fundador do Estoicismo, escola filosófica da qual fazia parte também Sêneca.

${ }^{14}$ Cleantes, discípulo e sucessor de Zenão.

${ }^{15}$ Outro estoico, discípulo de Cleantes.

${ }^{16}$ Os estoicos, provavelmente de Crisipo em diante, dividiam a lógica em duas partes: retórica e dialética. O que veio a ser chamado de "lógica" foi determinado por um conjunto de obras de Aristóteles que filósofos da Antiguidade nomearam Organon. Cf. Long, A. A. Hellenistic philosophy. Stoics, epicureans, sceptics. Berkeley and Los Angeles: University of California Press, 1986, p. 121-122.

${ }^{17}$ Cf. Long, op. cit., p. 95.

${ }^{18}$ Simplício (aproximadamente 490-560 d.C.) é, juntamente com Plotino, uma das principais fontes de evidência da teoria estóica das "categorias" (cf. von Arnim, H. F. A. Stoicorum ueterum fragmenta. Lipsiae: In aedibus B. G. Teubneri, 1903-24. Vol. II, p. 376-404; cf. ainda, Brun, J. O estoicismo. Tradução de João Amado. Lisboa: Edições 70, 1986, p. 43).

19 A distinção entre corporais e incorporais é um dos aspectos fundamentais da doutrina estoica. Esse aspecto faz parte de uma tese metafísica de que somente as coisas que podem ser consideradas como "existentes" são corpos. Enquanto um ser racional está pensando ou falando de maneira articulada, algo
} 
significa"; 3, a realidade material à qual o significado se refere. Nesse sentido Sexto Empírico, (que escreveu por volta do ano 200 de nossa era) ${ }^{20}$ dá, como exemplo, a palavra "Díon" e a frase "Díon está correndo". Naturalmente, o significado das palavras não deve ser confundido com a realidade física e material de um "Díon que corre", pois as palavras podem ser usadas e significar, isto é, atribuir significado, mesmo quando Díon está sentado. Nessa frase, o significado (lékton) ou, para usar um termo apropriado a esse tipo de significado, o axioma, ${ }^{21}$ é verdadeiro ou falso: verdadeiro se Díon está correndo quando as palavras estão sendo usadas; falso, se ele não está. Lékton, conceito fundamental para a "semântica" 22 estoica, pode ser traduzido, também, como "o que é dito" ou "o que pode ser dito". 23 Distinguem-se dois tipos de lékton: o "deficiente" $(\varepsilon \lambda \lambda \imath \pi \eta$, imperfectus $),{ }^{24}$ exemplificado pelo significado dos verbos sem sujeito (por

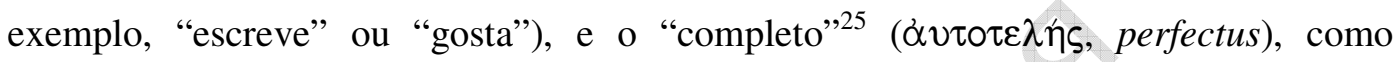
expresso na sentença “Catão está andando” (Diógenes Laércio, VII 63).

Não deixa de ser curioso que, apesar de, como veremos, preterir expressamente a lógica em passagens de sua obra filosófica, ${ }^{26}$ o filósofo Sêneca (4 a.C.-65 d.C.) faça uso de um exemplo similar ao de Sexto na epístola 117, ao explicar a Lucílio a noção de lékton (em latim, effatum, enuntiatum ou dictum):

...vejo Catão andando; o que o sentido me mostra, meu espírito toma por certo. O corpo é o que vejo, ao qual dirigi os olhos e o espírito. Em seguida, digo: Catão está andando. Não é um corpo, diz-se, aquilo de que falo agora, mas uma indicação a respeito de um corpo,

dotado de significado "coexiste" com seu pensamento (cf. Sexto Empírico, Ad. Math., VIII 70).

${ }^{20}$ Médico grego cujos escritos são a fonte principal da Escola Cética de filosofia. Sabe-se que sucedeu Heródoto na referida escola, mas pouco se sabe sobre detalhes de sua vida. Seus trabalhos que chegaram até nossos dias foram: Esboços do Pirronismo, em três livros; Contra os Dogmatas, Contra os físicos, Contra os eticistas e Contra os matemáticos [cf. Howatson, M. C. (org.). The Oxford companion to classical literature. Oxford/ New York: Oxford University Press, 1989 (sub uoce "Sextus Empiricus)].

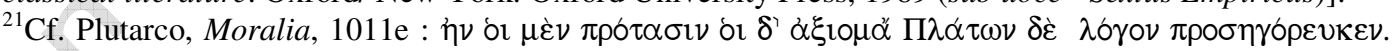
$\mathrm{O}$ termo axioma se refere à lógica estóica e à moderna.

22 "Semântica", como se sabe, palavra formada do grego $\sigma \eta \mu \alpha^{\prime} \mathrm{t} \omega$ ("significar") que, por sua vez, deriva de $\sigma \hat{\eta} \mu \alpha$ ("sinal"), é aqui entendida, lato sensu, como termo que se refere ao sentido e às palavras (cf. Guiraud, P. A Semântica. Tradução de Maria Elisa Mascarenhas. São Paulo: Difusão Europeia do Livro, 1972, p. 8).

${ }^{23}$ Cf. Long, op. cit., p. 135.

${ }^{24}$ Cf. Quintiliano, Institutio oratoria V 14, 1: Habet enim rationem et propositionem, non habet conclusionem: ita est ille imperfectus syllogismus ("Com efeito, tem uma razão e uma proposição, não tem conclusão: assim, esse é o silogismo incompleto" - minha tradução).

${ }^{25}$ Lékta completos em si mesmos incluem os axiomas, as questões, as interrogações, os imperativos, os juramentos, as invocações, as dúvidas, as imprecações e as hipóteses (Diógenes Laércio, Lives of eminent philosophers, VII 65-8).

${ }^{26}$ Cf. infra, Ep. 48 4-6; 10-12; 455 (nota 61, p. 12); 83 9-11. 
que alguns chamam 'expresso', outros 'indicado', outros 'dito',. ${ }^{27}$

Na passagem acima, no lékton "Catão está andando", não se está simplesmente denotando um objeto, está-se dizendo algo sobre ele. No mundo real não há duas coisas (Catão e o andar de Catão). ${ }^{28}$ O significado da palavra "Catão" é um homem individual. Porém, na frase "Catão está andando", abstrai-se, do homem real, algo que não tem existência independente - seu andar - e se confere referência a ele usando-se de um termo que denota ("Catão") e um termo que "diz algo" ("está andando"). ${ }^{29}$

A lógica formal, no estoicismo, tem seu ponto de partida no lékton. Em sua forma completa, o lékton tem o sujeito e o predicado como componentes, e os estoicos reconheciam nove tipos de asserção que preencheriam essa condição. ${ }^{30}$ Isso inclui questões, comandos, orações e juramentos, mas o mais importante de todos é o já referido axioma. Um axioma - frequentemente traduzido como "proposição"31 - é o lékton ao qual os predicados verdadeiros e falsos podem e devem ser aplicados (Diógenes Laércio VII, 65).

Sobre esse ponto, estudiosos ressaltam uma notável diferença entre a distinção estoica e a visão de Aristóteles, o qual supunha que o significado era idêntico ao pensamento; isto é, o que as palavras significam é um pensamento na mente do falante. ${ }^{32}$

Outra diferença já por nós apontada quanto aos termos que compõem o silogismo aristotélico e a proposição estoica, nomeadamente, a prioridade do indivíduo nesta última, surge, novamente, no tratamento estoico do silogismo. O raciocínio aristotélico trata do encadeamento de conceitos como "Sócrates é um homem; ora, todos os homens são mortais; logo, Sócrates é mortal", enquanto que o estoico trata das implicações de relações temporais (“Se esta mulher tem leite, é porque deu à luz"). ${ }^{33}$

Embora os peripatéticos estivessem cientes da existência desse tipo de

\footnotetext{
${ }^{27}$ Cf. Ep. 117, 13: Video Catonem ambulantem: hoc sensus ostendit, animus credidit. Corpus est quod uideo, cui et oculos intendi et animum. Dico deinde: Cato ambulat. Non corpus, inquit, est quod nunc loquor, sed enuntiatiuom quiddam de corpore, quod alii effatum uocant, alii enuntiatum, alii dictum. Para Lévy, na noção de lékton, cuja invenção parece remontar aos estóicos, destaca-se o senso de representação, inerente a esta e, principalmente, o objeto do discurso. Cf. Lévy, C. Les philosophies hellénistiques. Paris: Le livre de poche, 1997, p. 118-119.

${ }^{28}$ Cf. Long, op. cit., p. 136.

${ }^{29}$ Cf. Long, op. cit., p. 136.

${ }^{30}$ Cf. Long, op. cit., p. 140.

${ }^{31}$ Cf. supra, p. 89.

${ }^{32}$ Cf. Sandbach, op. cit., p. 97.

${ }^{33}$ Cf. Brun, op. cit., p. 37.
} 
silogismo, manifestavam pouco interesse por eles. ${ }^{34}$ Crisipo reconhecia cinco formas básicas de silogismos; cada um ligava um par de proposições, que ele representava pelas variáveis "primeira", "segunda". ${ }^{35}$

Inúmeros são os exemplos que mostram que os estoicos - e também autores não necessariamente estoicos ${ }^{36}$ - faziam uso prático de silogismos como esses. Dentre os autores romanos, destacamos um trecho do De divinatione, de Cícero:

Se (a) os deuses existem e (b) não preveem o futuro, ou (c) não nos amam, ou (d) eles não sabem o que vai acontecer, ou (e) eles não pensam que seria proveitoso que soubéssemos ou (f) eles não pensam que seria de acordo com a sua dignidade dizer-nos, ou (g) eles não estão aptos a nos contar. Mas não é verdade que eles não nos amam, nem que eles não sabem o que vai acontecer (...). Logo, não é verdade que os deuses existem e que não preveem o futuro. Mas os deuses existem. Logo, eles preveem o futuro. ${ }^{37}$

Até recentemente, muitos autores viam a lógica estoica como uma rival à aristotélica e demonstravam pouca disposição em entendê-la. Isso, para Sandbach, é um erro:

[a lógica estoica] não é, em sua essência, uma alternativa, mas um complemento, e o silogismo proposicional é reconhecido, hoje, como logicamente prioritário em relação ao silogismo de termos. Mas, embora a lógica estoica possa ser contrastada com a de Aristóteles, há pouca evidência de que ele tenha exercido grande influência em seu desenvolvimento (...). Há uma chance de que os estoicos tenham adaptado [os problemas de lógica] da escola megárica, ${ }^{38} \mathrm{em}$ todo caso, é evidente o interesse deles nos trabalhos dessa escola. ${ }^{39}$

Um aspecto que torna a lógica estoica particularmente interessante para os estudos da linguagem contemporâneos é sua abordagem do aspecto formal do discurso

${ }^{34}$ Cf. Sandbach, op. cit., p. 97. Segundo o autor, a importância desse tipo de proposição só foi reconhecida pelos lógicos a partir do século XIX.

${ }^{35}$ Utilizando, como Sandbach e Long, símbolos mais recentes como $p$ e $q$, eles podem ser esquematizados da seguinte maneira: (1) Se $p, q$. Mas p $\therefore$ q. (2) Se $p, q$. Mas não $q$. $\therefore$ Não $p$. (3) Não ambos $p$ e $q$. Mas $p$. $\therefore$ Não $q$. (4) Ou $p$ ou $q$. Mas $p \therefore$ Não $q$. (5) Ou $p$ ou $q$. Mas não $p . \therefore q$.

36 Apesar de não se definir como estoico, sabemos que M. T. Cícero (106-43 a.C.) caracteriza como estoicos, ou como simpatizantes do pensamento estoico, alguns dos personagens de seus diálogos filosóficos, como é o caso do protagonista de Cato Maior de Senectute. Sobre a filosofia de Cícero em geral, cf. Powell, J. G. F. (org.). Cicero the philosopher. Oxford: Clarendon Press, 1995.

${ }^{37} \mathrm{Cf}$. De diuinatione I 38, 82: Si sunt di neque ante declarant hominibus quae futura sint,(...). Sunt autem di; significant ergo (minha tradução).

${ }^{38}$ A escola megárica de filosofia foi fundada por Euclides de Mégara (390 a.C.), aluno de Sócrates. Seus membros adquiriram reputação devido a suas habilidades em argumentos dialéticos (cf. Howatson, op. cit., sub uoce "Megarian school").

${ }^{39}$ Cf. Sandbach, op. cit., p. 99. 
em si. O reconhecimento e a nomeação das partes do discurso, os casos dos nomes e os tempos verbais foram uma realização da escola estoica, adotada por Crates de Malos (século II a.C.) e, após ele, gramáticos fizeram sutis modificações nesse sistema. Os estoicos, porém, não separaram a análise gramatical - que concerne à forma das palavras e suas possíveis relações - da análise do significado. Uma das implicações disso é que eles distinguiam, como partes separadas do discurso, nomes próprios e comuns, o que consiste numa distinção de significado, não de gramática. ${ }^{40}$

\section{A importância da ética na filosofia de Sêneca: crítica aos silogismos}

$\mathrm{Na}$ escola filosófica fundada por Zenão de Cicio, a conhecida tripartição da filosofia em física, lógica e ética, ainda que tenha sido iniciada pelo acadêmico Xenócrates (339- 314 a.C.), encontrou, entre os estoicos, um sistema cuja "perfeição" eles mesmos não cansavam de exaltar. ${ }^{41}$ A ordem adotada com mais frequência lógica, física e ética - foi instituída pelo próprio Zenão, que acabou por privilegiar a ética. Outros estoicos, como Panécio e Possidônio, começavam pela física, acreditando que o conhecimento do mundo é o ponto de partida para toda pesquisa filosófica. ${ }^{42}$

À parte as ordens adotadas pelos diversos mestres do Pórtico, o estoicismo passou por diferentes fases desde sua origem até chegar à chamada terceira fase, ou Neoestoicismo, da qual Sêneca é o expoente. O Neoestoicismo se caracterizou, especialmente, por abandonar a lógica e a física em benefício da moral. ${ }^{43}$ De acordo com as supostas tendências pragmáticas da índole romana, a Estoa, uma vez transplantada para Roma, foi acentuando cada vez mais seu caráter eticista. ${ }^{44}$ E Sêneca, por sua vez, oferece um padrão tripartite de orientação ética: avaliar o valor de cada coisa, adotar um impulso (impetus) apropriado em direção ao que se persegue e adquirir consistência entre o impulso e a ação. ${ }^{45}$

${ }^{40}$ Cf. Sandbach, op. cit., p. 100.

${ }^{41}$ Cf. Lévy, op. cit., p. 112.

${ }^{42}$ Cf. Lévy, op. cit., p. 113.

${ }^{43}$ Cf. Brun, op. cit., p. 15.

${ }^{44}$ Cf. Besselaar, J. van Den. O progressismo de Sêneca. Assis: Faculdade de Filosofia, Ciências e Letras, 1960 , p. 14.

${ }^{45}$ Cf. Ep. 89, 14: Ego cum tripertita sit philosophia, moralem eius partem primam incipiamus disponere. Quam in tria rursus diuidi placuit, ut prima esset inspectio suum cuique distribuens et aestimans quanto quidque dignum sit, maxime utilis. Quid enim est tam necessarium quam pretia rebus inponere? Secunda de impetu, de actionibus tertia. Primum enim est, ut quanti quidque sit iudices, secundum, ut impetum ad illa capias ordinatum temperatumque, tertium, ut inter impetum tuum actionemque conueniat, ut in omnibus istis tibi ipse consentias ("Logo, sendo a filosofia dividida em três partes, comecemos a dispor, em primeiro lugar, sua parte moral. Esta, por sua vez, também deve ser dividida em três, de modo que a 
Para Sêneca, nenhum estudo filosófico teria valor se não pudesse ser utilizado na vida prática: o interesse principal do cordovês consistia na formação moral de seus discípulos. E, para isso, na opinião do estoico, há que se guiá-los pelas vias da filosofia. Nesse contexto, os silogismos da dialética seriam, ao menos em princípio, inúteis, como mostra claramente uma passagem da epístola 48:

Prefiro, ó Lucílio, excelente entre os homens, que esses sujeitos minuciosos ${ }^{46}$ me ensinem que serviço prestar a um amigo, a um ser humano, a me ensinarem de quantas maneiras se pode dizer "amigo" e quantos sentidos pode ter o termo "ser humano"(...). "Rato é uma sílaba, e rato rói queijo: logo, a sílaba rói o queijo". Pensa, agora, que eu não posso resolver esse silogismo: que perigo me ameaça essa ignorância? Que incômodo? Sem dúvida, devo ter receio de capturar as sílabas na ratoeira ou, se eu for mais descuidado, de o livro comer meu queijo. A menos que haja um raciocínio ainda mais aguçado: "Rato é uma sílaba ${ }^{48}$, e sílaba não rói queijo; logo, o rato não rói o queijo'. Oh, baboseiras infantis! É para isso que franzimos as sobrancelhas? É para isso que deixamos a barba crescer? É isso que ensinamos, soturnos e pálidos? Queres saber o que a filosofia promete ao gênero humano? Bom senso (...)".49

No entanto - e para que não caiamos no maniqueísmo -, é preciso admitir que Sêneca usa silogismos a seu favor em outras epístolas. Isso fica mais claro, por exemplo, na epístola 85, em que esse tipo de construção dialéticas serve para ensinar a Lucílio precisamente problemas de ordem moral. Para reconhecer a presença dos silogismos, é necessário que se analise a carta com maior atenção. ${ }^{50}$

Respondendo a uma possível dúvida de seu discípulo, Sêneca começa a expor os

primeira, a especulativa, atribui o que cabe a cada um e avalia o quanto vale cada coisa; é extremamente útil. De fato, o que é tão indispensável quanto estimar o valor das coisas? A segunda trata do impulso; a terceira, das ações. Com efeito, em primeiro lugar deves avaliar o valor de cada coisa; em segundo, deves atribuir a cada uma um impulso regulado e justo; em terceiro, o impulso e as ações devem estar de acordo entre si, para que em tudo isso estejas de acordo contigo mesmo" - minha tradução).

${ }^{46}$ Fala-se, aqui, dos epicuristas e dos estoicos.

47 "Para o estóico, os termos "amigo" e "ser humano" são coextensivos; ele é o amigo de todos, e seu motivo para a amizade é estar a serviço. O epicurista, no entanto, restringe a definição de "amigo" e o tem meramente como um instrumento de sua própria felicidade”. Cf. Seneca. Epistles (1-65). With an English translation and notes by R. M. Gummere. Cambridge, Mass./ London: Harvard University Press, 1917, p. 316 Nota "a".

${ }^{48}$ Sêneca joga com a palavra "rato" que, em latim, é um monossílabo ( $m u s$ ), daí as traduções "rato é uma sílaba" e " $a$ sílaba rói o queijo".

${ }^{49}$ Hoc, Lucili uirorum optime, mihi ab istis subtilibus praecipi malo, quid amico praestare debeam, quid homini, quam quot modis amicus dicatur, et homo quam multa significet (...). "Mus syllaba est: mus autem caseum rodit: syllabam ergo caseum rodit". Puta nunc me istuc non posse soluere: quod mihi ex ista inscientia periculum inminet? quod incommodum (...)... quid philosophia promittat generi humano? Consilium (...) - minha tradução.

${ }^{50}$ Por questão de clareza nos referimos aqui às diversas passagens da carta 85 , cuja tradução parcial é apresentada ao final do texto. 
raciocínios pelos quais a Estoa demonstra que a virtude basta à felicidade $(\S 1)$. Ele defende um de seus raciocínios contra as críticas dos peripatéticos, que pretendem não que se suprimam as paixões, mas que se somente as moderem (§ 2-4). Elas, no entanto, não permitem qualquer moderação ( $\$$ 5-13). Uma afecção da sensibilidade poder-se-á tornar, se tolerada, um vício ( $\$ 14$ e 15). O medo, uma vez admitido na alma do sábio, não permitirá a ele sacrificar-se verdadeiramente por amor à pátria (§ 16).

Sêneca prova, em seguida, que não se podem conceber "níveis" na felicidade (§ 17-23). Xenócrates, como Epicuro, não sustenta que o honestum (isto é, a virtude) seja o único bem (§ 18). A vida totalmente feliz (o que implica a obtenção do summum bonum, ou "bem supremo") não irá regredir (§ 19-20). É-se feliz da mesma forma que se é satisfeito ou inalterado, por exemplo (\$23).

$\mathrm{O}$ raciocínio senequiano passa a se fundar na definição dos verdadeiros males. $\mathrm{O}$ medo não tem como objeto os verdadeiros males, mas aquelas coisas consideradas “más” pela opinião pública ( $\$ 24-29)$. Essa ideia se liga a outro raciocínio, desenvolvido consecutivamente, baseado no fato de que, diferentemente do que se costuma pensar, não são males o sofrimento e a pobreza, visto que não podem prejudicar o sábio, cujo valor eles não diminuem. A tempestade não rouba a arte do piloto, por assim dizer (3036). O sábio realizará sua tarefa não importa qual seja sua sorte, se boa ou ruim. Em seguida, para ilustrar mais uma vez o que acaba de dizer, Sêneca dá o exemplo do escultor Fídias, ${ }^{51}$ que faria belas esculturas seja qual fosse o material dado a ele: bronze, mármore etc. (§ 37-40). O trabalho do sábio é domesticar os males $(\S 41){ }^{52}$

Observemos, a título de exemplo, como se confrontam o ponto de vista estoico e aristotélico num trecho da referida carta em que Sêneca, mencionando a arte de pilotar, faz ele mesmo uso de um silogismo para explicar que os "males" não podem prejudicar o sábio:

30. "O que é um mal causa prejuízo; o que causa prejuízo torna pior. A dor e a pobreza não tornam ninguém pior; portanto, não são males".

"É falsa", diz-se, "vossa proposição, pois, se algo causa prejuízo, não necessariamente torna pior. $\mathrm{O}$ mau tempo e a tormenta causam prejuízo ao piloto, e, no entanto, não o tornam

\footnotetext{
${ }^{51}$ Fídias (490-432 a.C.), um dos grandes artistas atenienses, famoso especialmente como escultor, mas também como pintor e arquiteto (cf. Howatson, op. cit., sub uoce "Pheidias").

${ }^{52} \mathrm{O}$ raciocínio indutivo não é um mecanismo da escola estóica, mas da aristotélica, que "versa sobre a extensão dos conceitos e procura descobrir relações de inclusão ou de exclusão, procedendo do particular para o geral (indução) ou do geral para o particular (dedução)”. Cf. Brun, op. cit., p. 36.
} 
pior". 31. Alguns estoicos, a essa afirmação, assim respondem: o piloto fica pior por causa do mau tempo e da tormenta porque não consegue, como havia proposto, nem levar a cabo nem manter seu curso; ele não fica pior em sua habilidade, ele o fica na execução da tarefa. Alguns peripatéticos replicam: "Portanto, a pobreza tornará pior inclusive o sábio, e também a dor ou qualquer outro mal semelhante; não lhe arrebatará a virtude, mas atrapalhará sua execução". 32. Essa seria uma afirmação correta se a condição do piloto e a do sábio não fossem diferentes. Pois, ao primeiro, não foi estabelecido que, na vida, cumprisse sem exceção e com perfeição suas ações, mas que tudo fizesse da maneira correta. Ao piloto foi estabelecido que, em qualquer situação, conduzisse o navio até o porto. As artes são auxiliares, devem cumprir o que prometem; a sabedoria é senhora e governadora. As artes servem à vida, a sabedoria é rainha. ${ }^{53} 33$. Da minha parte, penso que se deve dar ainda outra resposta: nem a habilidade do piloto fica pior com qualquer mau tempo, nem seu próprio exercício. O piloto não te prometeu um bom êxito, e, sim, um trabalho eficaz e o conhecimento de dirigir o navio. Isso se torna mais evidente quanto mais acontecimentos fortuitos lhe surgem como obstáculo. Quem pôde dizer "Netuno, nunca dirigi meu navio a não ser em linha reta", usou de habilidade o suficiente. O mau tempo não impede o trabalho do piloto, mas seu bom êxito. 34. "E então?", diz-se, "não causa prejuízo ao piloto essa situação que o impede de chegar ao porto, que torna seus esforços inúteis, que ora o faz retroceder, ora o retém e o desarma?" Não lhe causa prejuízo enquanto piloto, mas enquanto navegante; de outra forma ele não é piloto; não impede $^{54}$ em absoluto a habilidade de um piloto, mas a evidencia: pois, como dizem, "em mar tranquilo todo mundo é piloto". Essas situações trazem danos à embarcação, não a seu comandante - enquanto comandante. 35 . De duas pessoas se compõe o piloto: uma, em comum com todas as que embarcaram no navio e através da qual ele próprio é passageiro; outra, que lhe é própria: o piloto. O mau tempo lhe causa prejuízo enquanto passageiro, não enquanto piloto. 36. Ademais, a habilidade do piloto é um bem alheio: diz respeito aos que transporta, tal como a do médico aos que cura. $\mathrm{O}$ bem comum é o do sábio: diz respeito àqueles com quem vive e a ele próprio. Assim, talvez o piloto possa ser prejudicado, cujo serviço prometido a outros é impedido pelo mau tempo. 37 . O sábio não é prejudicado pela pobreza, nem pela dor, nem pelas outras tempestades da vida. ${ }^{55}$

\footnotetext{
${ }^{53}$ Cf. Ep. 53, 9.

${ }^{54}$ Sc. a situação que impede o piloto de chegar ao porto, sobre a qual se discorria.

${ }^{55}$ Quod malum est, nocet (...) non ab aliis tempestatibus uitae. Por questões de espaço, suprimimos o trecho completo em latim (minha tradução).
} 
É a partir da exposição de um silogismo de caráter peripatético ("O que é um mal que causa prejuízo" etc.) que Sêneca expõe diferenças entre a opinião dos estoicos e a dos peripatéticos. No parágrafo 31 , aqueles, em resposta à afirmação desses últimos (encontrada no parágrafo 30), dizem que não é a habilidade do piloto que fica pior com o mau tempo e com a tormenta, mas sim que esses contratempos o atrapalham na execução da tarefa de pilotar ( $§ 31)$. Os peripatéticos, por sua vez, replicam que a pobreza, a dor ou "males" semelhantes atrapalharão a execução da uirtus pelo sapiens (idem).

Expostas as opiniões das duas escolas filosóficas, Sêneca primeiramente nega a pertinência da indução no parágrafo 32 ("Essa seria uma afirmação correta se a condição do piloto e a do sábio não fossem diferentes" etc.). Um pouco mais adiante, ele refuta o ponto de vista estoico ${ }^{56}$ anteriormente citado ( $\left.\$ 31\right)$ : "O mau tempo não impede o trabalho do piloto, mas seu bom êxito" ( $(33)$.

No parágrafo 35, chama-nos atenção a minuciosidade na separação dos significados e a redefinição dos mesmos ${ }^{57}$ ("De duas pessoas se compõe o piloto: uma, em comum com todas as que embarcaram no navio e através da qual ele próprio é passageiro; outra, que lhe é própria: o piloto").

Um outro exemplo nesse sentido se dá na Ep. 83, quando Sêneca refuta a veracidade de um silogismo de Zenão em que ele inferira que o homem de bem não ficaria bêbado. O silogismo é o seguinte: "Ninguém comenta um assunto confidencial com um bêbado; ora, com um homem de bem comenta. Logo, o homem de bem não ficará bêbado" (Ep. 83, 9).

Importante é notar que, aqui, Sêneca não somente expõe a falsidade das premissas como acrescenta que há "uma enorme diferença entre um bêbado (ebrium) e um embriagado (ebriosum). Quem está bêbado pode estar pela primeira vez e não

\footnotetext{
${ }^{56}$ Procedimento verificável em outras obras do filósofo, como, por exemplo, na $E p$. 83. Aqui, ao refutar a veracidade de um silogismo de Zenão (Ebrio secretum sermonem nemo committit, uiro autem bono committit: ergo uir bonus ebrius non erit - "Ninguém comenta um assunto confidencial com um bêbado; ora, com um homem de bem se comenta. Logo, o homem de bem não ficará bêbado" - § 9), Sêneca joga com outro silogismo (Dormienti nemo secretum sermonem committit, uiro autem bono committit: uir bonus ergo non dormit - "Ninguém comenta um assunto confidencial com alguém que está dormindo; ora, com um homem de bem comenta. Logo, o homem de bem não dorme") para mostrar que a argumentação de Zenão é falsa.

57 A revisão do significado dos termos é procedimento constante no raciocínio de Sêneca. Sobre a diferença entre "vida" (uita) e "tempo" (tempus), fundamental à argumentação desenvolvida na primeira carta a Lucílio, tratamos em Tempus em Sêneca: abordagem de um conceito-chave. Phaos. Campinas, vol. 4, p. 39-57, 2004, fruto de trabalho de Iniciação Científica (FAPESP número 02/07359-0), orientado pelo professor Dr. Paulo Sérgio de Vasconcellos (IEL-Unicamp).
} 
possuir esse vício, e quem está embriagado, com frequência, não está bêbado" ( $\$ 11){ }^{58}$

Os exemplos de "redefinição de termos na obra de Sêneca são vários, e não se restringem às Epistulae. ${ }^{59}$

\section{Observações finais}

Neste estudo, que partiu de distinções entre a lógica aristotélica e a estoica, vemse, entretanto, elucidar diferenças entre a lógica estoica e a lógica do próprio Sêneca. Notou-se, através dos exemplos acima, que o cordovês muitas vezes pretere a lógica ${ }^{60} \mathrm{e}$ enfatiza a moral. Trata-se, como comentamos, de uma tendência na história do estoicismo esse crescente privilégio da moral. Mas é interessante que Sêneca critica o uso do silogismo lógico mesmo quando este pretende servir à moral: vimos que o próprio cordovês trata jocosamente o uso do silogismo por Zenão, que busca afastar seus discípulos da bebida através desse tipo de argumentação $(E p .83,9)$.

Um contraste com esse comportamento constatamos no trecho da Ep. 85, em que também Sêneca faz uso de silogismos ("O que é um mal causa prejuízo; o que causa prejuízo torna pior. A dor e a pobreza não tornam ninguém pior; portanto, não são males"), tipo de construção criticada por ele próprio em carta anterior (Ep. 48). Na 85, porém, o filósofo tenta convencer seu discípulo de que a dor e a pobreza, consideradas como males pela opinião comum, não são na verdade "males", e também de que eles não podem prejudicar o sábio, comparado, nessa carta, a um piloto. O mesmo procedimento foi por nós percebido na $E p$. 83, em que, ao partir da crítica ao silogismo de Zenão, Sêneca, no parágrafo 26, assim adverte Lucílio:

Quase sempre a violência vem depois da embriaguez pelo vinho; com efeito, a integridade do espírito se deteriora e se agrava. Assim como doenças prolongadas deixam os doentes insaciáveis nas queixas e difíceis de lidar, e irritados com a menor contrariedade, também as bebedeiras constantes enfurecem as almas. Pois, quando com frequência não se tem o domínio de si, a loucura passa a ser um

\footnotetext{
${ }^{58}$ Plurimum (...) interesse concedes et inter ebrium et ebriosum: potest et qui ebrius est, tunc primum esse nec habere hoc uitium, et qui ebriosus est, saepe extra ebrietatem esse.

${ }^{59} \mathrm{Cf}$., ainda, De otio IV 1 e De breuitate uitae XII 1, 6.

${ }^{60}$ Cf., ainda, Ep. 45, 5: Multum illis temporis uerborum cauillatio eripuit, captiosae disputationes quae acumen irritum exercent. Nectimus nodos et ambiguam significationem uerbis illigamus ac deinde dissoluimus: tantum nobis uacat? iam uiuere, iam mori scimus? Tota illo mente pergendum est, ubi prouideri debet, ne res nos, non uerba, decipiant ("Jogos de palavras lhes tomaram muito de seu tempo, e discussões sofísticas que estimulam sutilezas ineficazes. Ficamos dando nós, atamos um sentido ambíguo às palavras e depois os desatamos. Temos tempo de sobra? Já sabemos viver, já sabemos morrer? Devemos continuar, com toda a força do espírito, em direção a esse caminho, onde se deve ter cuidado para que as ações não nos iludam, e não as palavras" - minha tradução).
} 
hábito, e os vícios que surgem do vinho subsistem mesmo sem ele. ${ }^{61}$

Nota-se, portanto, que mesmo a crítica de um silogismo é ponto de partida para uma salutar lição moral, objetivo maior de Sêneca na formação de seus discípulos. ${ }^{62}$

\section{Referências}

ALBERTINI, E. La composition dans les ouvrages philosophiques de Sénèque. Paris: Éditions de Boccard, 1923.

von ARNIM, H. F. A. Stoicorum ueterum fragmenta. Leipzig: B.G. Teubner, 1903-24.

BESSELAAR, J. van Den. O progressismo de Sêneca. Assis: Faculdade de Filosofia, Ciências e Letras, 1960.

BETH, E. W. Aspects of modern logic. Dordrecht: D. Reidel, 1970.

BOBZIEN, S. Lógica. In: Os estoicos. Tradução de Paulo Fernando Tadeu Ferreira e Raul Fiker. São Paulo: Odysseus, 2006, p. 95-138.

BREGALDA, M. M. Sapientia e uirtus: princípios fundamentais no estoicismo de Sêneca. Campinas: IEL-UNICAMP, 2006 (dissertação de mestrado).

Tempus em Sêneca: abordagem de um conceito-chave. Phaos. Campinas, vol. 4, p. 39-57, 2004.

BRUN, J. O estoicismo. Tradução de João Amado. Lisboa: Edições 70, 1986.

CERQUEIRA, L. A.; OLIVA, A. Introdução à lógica. Rio de Janeiro: Zahar, 1982.

CHAUVINEAU, J. A lógica moderna. Tradução de André Infante. Lisboa: EuropaAmérica, 1957.

\footnotetext{
${ }^{61}$ Fere uinolentiam crudelitas sequitur: uitiatur enim exasperaturque sanitas mentis. Quemadmodum inexplebiles querendi difficilesque faciunt diutini morbi et ad minimam rabidos offensionem, ita ebrietates continuae efferant animos. Nam cum saepe apud se non sint, consuetudo insaniae durat ac uitia uino concepta etiam sine illo ualent.

${ }^{62}$ Cf. supra, p. 95.
} 
CHIERCHIA, G. Semântica. Tradução de Luis Arthur Pagani, Lígia Negri e Rodolfo Ilari. Campinas/ Londrina: UNICAMP/ EDUEL, 2003.

CICÉRON. De la divination. Traduction et notes par Charles Appuhn. Paris: Garnier Frères, 1937.

CONTE. G. B. Latin literature: a history. Baltimore/ London: John Hopkins University Press, 1994.

DIOGENES LAERTIUS. Lives of eminent philosophers. With an English translation by R. D. Hicks. Cambridge, Mass./ London: Harvard University Press, 2000. Vol. II.

GLARE, P. G. W. (org.). Oxford Latin dictionary. New York: Oxford University Press, 1982.

GUIRAUD, P. A Semântica. Tradução de Maria Elisa Mascarenhas. São Paulo: Difusão europeia do livro, 1972.

HOWATSON, M. C. (org.). The Oxford companion to classical literature. Oxford/ New York: Oxford University Press, 1989.

INWOOD, B. (org.). Os estoicos. Tradução de Raul Fiker. São Paulo: Odysseus, 2006.

LÉVY, C. Les philosophies hellénistiques. Paris: Le livre de poche, 1997.

LIDDELL; SCOTT. A Greek-English lexicon. Oxford: Clarendon Press, 1996.

LONG, A. A. Hellenistic philosophy. Stoics, epicureans, sceptics. Second edition. Berkeley and Los Angeles: University of California Press, 1986.

PLATON. Phédon. Texte établi et traduit par Paul Vicaire. Paris: Les Belles Lettres, 1995.

PLUTARCH. Moralia. With an English translation by Harold Cherniss. Cambridge, Mass./ London: Harvard University Press, 2000. Vol. XIII.

POWELL, J. G. F. (ed.). Cicero the philosopher. Oxford: Clarendon Press, 1995.

QUINTILIAN. Institutio oratoria. With an English translation by H. E. Butler. Cambridge, Mass./ London: Harvard University Press, 1995. Vol. IV-VI. 
REALE, G. Lucio Anneo Seneca. Tutte le opere. Milano: Edizione Bompiani, 2000.

SANDBACH, F. H. The stoics. Second edition. Cambridge: Bristol Classical Press, 1989.

SEGURADO E CAMPOS, J. A. Cartas a Lucílio. Lisboa: Gulbenkian, 1991.

SENECA. Epistles (1-65). With an English translation and notes by R. M. Gummere. Cambridge, Mass./ London: Harvard University Press, 1917.

Lettres à Lucilius. Texte établi par François Préchac et traduit par Henri Noblot. Paris: Les Belles Lettres, 1993. Tome II.

. Lettres à Lucilius. Texte établi par François Préchac et traduit par Henri Noblot. Paris: Les Belles Lettres, 1987. Tome IV.

. Lettres à Lucilius. Texte établi par François Préchac et traduit par Henri Noblot. Paris: Les Belles Lettres, 1991. Tome V. 